\title{
A francia védelmi kiadásokról a 2019-2025-ös védelmi költségvetési törvény alapján
}

\begin{abstract}
Az elemzés a 2017-es francia Védelmi és Nemzeti Biztonsági Stratégiai Felülvizsgálat stratégiai célkitüzéseinek végrehajtási módjára fókuszál a 2019-2025-ös francia védelmi költségvetési törvény feladatszabó elemeinek és a jelenlegi müveleti mandátumok túlterheltségéből eredő kihivásoknak az összevetésén keresztül. Az előző programtörvény tükrében mutatja be a 2019-2025-ös költségvetés fö prioritásait, ütemezését és pénzügyi szabályozását, valamint a képességfejlesztésre és eszközbeszerzésre fordított kiadások arányát. A francia múveleti kihívások elemzése alapján vizsgálja az új célkitüzések elérését támogató stratégiák korlátait és lehetőségeit, így a müveleti költségvetési keret növelésének, a müveletek átstrukturálásának, valamint a többoldalú védelempolitikai együttmüködések elmélyítésének esélyeit. Végezetül az új védelmi költségvetési törvény kilátásait elemzi politikai gazdaságtani tényezők alapján.
\end{abstract}

Kulcsszavak: Macron, Franciaország, védelmi kiadások, költségvetési törvény, katonai müveletek

Nádudvari Anna: On the French Defence Expenditures in the Light of the 20192025 Military Programming Law

This article focuses on the implementation of French strategic priorities of the 2017 Strategic Review of Defence and National Security by comparing the tasks introduced in the 2019-2025 Military Programming Law to the realities of present operational mandates. The paper introduces the main priorities and schedule of the 2019-2025 Military Programming Law, as well as the proportional expenses in capacity development and procurement choices; and compares these to the previous defence expenditure cycle. The paper further identifies opportunities and limits in the strategies of the increased operational expenses, the restructuring of operational deployments, as well as in the development of multilateral defence cooperations. The prospect of the complete implementation of the new programming law is analysed in the context of political economy conditions.

Keywords: Macron, France, defence expenditures, Military Programming Law, military operations

\section{A védelmi költségvetési törvény Macron elnök védelempolitikai kezdeményezéseinek kontextusában}

Emmanuel Macronnak a Sorbonne egyetemen tartott 2017. szeptemberi beszéde az elnök európai uniós szakpolitikákhoz kapcsolódó kezdeményezéseinek megalapozását szolgálta, 
egyúttal Franciaország Európában betöltött szerepét is kijelölte. ${ }^{1}$ Az „Európai kezdeményezés" (Initiative pour l'Europe) védelempolitikai elemeit a 2017 októberében megjelent Védelmi és Nemzeti Biztonsági Stratégiai Felülvizsgálat (Revue Stratégique De Défense Et De Sécurité Nationale, továbbiakban: Stratégiai Felülvizsgálat) erősítette meg. ${ }^{2}$ A Stratégiai Felülvizsgálat a 2019-2025-ös védelmi költségvetési törvényt (Loi Programmation Militaire - LPM) készítette elő a képességfejlesztési és modernizációs prioritások meghatározásával. ${ }^{3}$ A törvénytervezetet 2018. február 8-án mutatták be, majd 2018. március 27-én fogadta el a Nemzetgyülés.

A védelmi költségvetési törvény egy újabb mérföldkő a Macron elnöksége alatt formálódó védelempolitikai kezdeményezések sorában. Az elnök beiktatását követően mindössze négy hónap alatt elkészült Stratégiai Felülvizsgálat mellett megújították a hírszerzési és terrorellenes szervek koordinációját. ${ }^{4}$ A 2018-as pénzügyi év védelmi költségvetését 1,8 milliárd euróval emelték, elérve ezzel a 34,2 milliárd eurót. ${ }^{5} 2017$ decemberében pedig francia részvétellel az Állandó Strukturált Együttmüködés (Permanent Structured Cooperation - PESCO) európai szinten intézményesítette a védelempolitika közösségi lehetőségeit. A fóbb francia műveleteket érintő változások közé tartozik a Sentinelle-művelet átstrukturálása, a G5 Száhel-erők kialakításának támogatása és az „Iszlám Állam” sikeres visszaszorítása a Közel-Keleten.

Macron elnök 2018 januári beszédében kiemelte: az új védelmi költségvetési törvény folyamatos költségvetés-emelése a korábbi évek alulfinanszírozottságából eredő visszás hatásokat igyekszik ellensúlyozni azzal a céllal, hogy a 2030-ra kitűzött védelmi ambíciókat megalapozza. ${ }^{6}$ A védelmi költségvetési törvényben meghatározott keretek és a Stratégiai Felülvizsgálatban megjelenő elvek és prioritások tükrözik a francia védelmi szférát leginkább foglalkoztató problémákat és az azokra adott válaszokat, ezért kiemelten fontos ezek értékelése.

\section{A 2019-2025-ös védelmi költségvetési törvény fő elemei}

A 2019-2025-ös védelmi költségvetési törvény a védelmi képességek „átfogó és kiegyensúlyozott" fejlesztésén, azaz a teljes spektrumú haderőmodell (modèle d’armée complet et équilibré) elvén alapul, egyúttal megerősíti a korábbi védelmi költségvetési törvényben (2014-2019) elindított beszerzési és modernizációs programokat. A 2019-2025-ös ciklus

Initiative pour l'Europe - Discours d'Emmanuel Macron pour une Europe souveraine, unie, démocratique, [online], 2017. 09. 26. Forrás: Elysee.fr [2017. 11. 07.]

2 Revue Stratégique De Défense Et De Sécurité Nationale, [online], 2017. Forrás: Defense.gouv.fr [2017. 10. 15.]. A 2017es francia stratégiai felülvizsgálat elemzését bővebben lásd: NÁDUDVARI Anna: A 2017-es francia stratégiai felülvizsgálat értékelése, [online], Nemzet és Biztonság, 11. évf., 2018/3. 55-78. o.

3 Loi de programmation militaire 2019-2025: textes officiels, [online], 2018. 02. 16. Forrás: Defense.gouv.fr [2018. 03. 07.]

4 La loi renforçant la sécurité intérieure et la lutte contre le terrorisme (SILT)Décret $\mathrm{n}^{\circ}$ 2017-1095, [online], 2017. 06. 14. Forrás: Legifrance.gouv.fr [2018. 03. 01.]

5 A francia védelmi költségvetés az állam költségvetési keretének meghatározó hányadát adja. 2017-ben az állami költségvetés (nem azonos a GDP-arányos ráfordítással) 13,6\%-át tette ki a védelmi minisztérium költségvetése (a katonai nyugdíjakat nem számítva ez az arány 10,2\%), ezt egyedül az oktatásra fordított források aránya előzte meg. Chiffres clés de la Défense - 2017, [online], 2017. Forrás: Defense.gouv.fr [2017. 11. 01.]

6 Discours du Président de la République, Emmanuel Macron, vœux aux Armées, [online], 2018. 01. 23. Forrás: Elysee.fr [2018.03.01.] 
295 milliárd eurós összköltségvetéssel tervez. Ebben az időszakban megkezdődik a nagy fegyverkezési programok előkészítő szakasza, átlagosan 1,8 milliárd euró éves kerettel. Idetartozik a Charles de Gaulle repülőgép-hordozó utódlását felmérő tanulmányok megkezdése, valamint a következő generációs harckocsi- és légiharci rendszerek fejlesztései, amelyek 2030 után állnának majd szolgálatba. Macron a francia nukleáris elrettentési startégiát „elidegeníthetetlen történelmi hagyománynak” nevezte, és az ország stratégiai autonómiáját garantáló eszközként értékelte. A védelmi költségvetési törvény alapján az elrettentési funkció fenntartása érdekében sor kerül a tengeri és légi nukleáris komponensek megújítására, ennek éves kerete a 2017-es 3,9 milliárd euróról évi 6 milliárd euróra emelkedik 2025-ig, azaz a ciklus során összesen 37 milliárd eurót költenek a nukleáris képességek modernizációjára.

A 2019-2025-ös védelmi költségvetési törvény négy pillért határoz meg. Az első két pillér a haderő rövid távú, azonnali szükségleteire irányul, így idetartozik a katonák életszínvonalának és a hadsereg funkcionális képességeinek javítása; a felszerelés modernizálása és a képességhiányok betöltése. A harmadik és negyedik pillér az európai együttmüködések és az innováció területeire fókuszálva a stratégiai autonómia fejlesztésére irányul.

Az 1. pillér a műveletek fenntarthatóságát és a műveleti fáradtság enyhítését célozza, ebben a kiszolgáló és támogató funkciók fejlesztése és a haderő humánerőforrás-problémáinak megoldása az elsődleges. Idetartoznak a személyi felszerelések (új golyóálló mellények, kézifegyverek $)^{7}$ és az infrastruktúra megújítására, valamint a katonák életszínvonalának és munkakörülményeinek javítására irányuló kezdeményezések, mint például a katonacsaládok életminőségének javítását célzó intézkedések. Az infrastruktúra-karbantartáshoz és az új eszközök működtetéséhez szükséges kiszolgáló-támogató struktúrák modernizációjára szánt keret már a 2018-as pénzügyi év költségvetésében 1,3-ról 1,5 milliárd euróra emelkedett. $^{8}$

A hiányzó humán erőforrás pótlása érdekében erősítik a műveleti tartalékos rendszert, amelyben az éves szolgálat maximális időtartama 60 napra nő. A fegyveres erők moráljának általános javítása érdekében 2019-2025 között 300 millió eurót szánnak a katonák és katonacsaládok életszínvonalának és lakhatási körülményeinek javítására. ${ }^{9}$ Erre a célra már 2018-ban 22 millió eurót fordítanak az úgynevezett „Családi terv” keretében. ${ }^{10} \mathrm{~A}$ humánerőforrás-hiány orvoslása érdekében 6000 fövel tervezik bővíteni a haderőt, ezen belül 2019-2023 között 3000 fővel növelnék a Védelmi Minisztérium (Ministère des Armées) állományát. Emellett már a 2018-as védelmi költségvetési keret 500 új munkahely kialakítást

A francia kézifegyveripar fejlesztésének kudarcát jelzi, hogy a francia haderő a német Heckler \& Koch 416F kézifegyverek alacsony költségü (100 millió euró) beszerzése mellett döntött. Quelles priorités, quels défis pour la loi de programmation militaire 2019-2024? [online], 2018. 02. 07. Forrás: Jean-jaures.org [2018. 04. 01.]

8 Jean-Michel Jacques, a Nemzetgyülés Védelmi Bizottságának alelnöke szerint jól jelképezi a kiszolgáló funkciók gyengeségét a müveleti felszerelések biztosítása terén, hogy egy megfigyelő drón beszerzési folyamata gyorsított eljárásban hat hónapig, általános eljárásban akár három évig is eltarthat. Défense: «Nos armées doivent acquérir plus rapidement leurs équipements opérationnels», [online], 2018. 03. 27. Forrás: LeMonde.fr [2018. 04. 01.]

9 Florence Parly présente le Plan d’accompagnement des familles et d'amélioration des conditions de vie des militaires 2018-2022, [online], 2017. 10. 31. Forrás: Defense.gouv.fr [2017. 11.07.]

10 Pierre Alonso: La ministre des Armées veut améliorer le quotidien des militaires, [online], 2017. 10. 31. Forrás: Liberation.fr [2017. 11. 07.] 
célozza a védelmi szférában. A programterv szerint a tervezett bővítésekkel a haderő létszáma 2025-re elérheti a 274936 főt. A humán erőforrás bővítésében kiemelt jelentőséggel bír a hírszerzés (+1500 fó), a kibervédelem (+1500fö), a Védelmi Minisztérium biztonságának és ellenálló képességének erősítése (+750 fő), a védelmi ipari export (+400fö), valamint a müveleti támogatás (elsősorban a haderő egészségügyi szakállománya).

A 2. pillérben a teljes spektrumú haderőmodell vezérlőelve alapján a hagyományos képességek gyorsított modernizálása és a képességhiányok betöltése mindegyik haderőnem kapcsán megjelenik. A szárazföldi erőknél a Scorpion program keretében a páncélozott harcjármüvek felét modernizálják 2025-ig (a jármüvek maradék 50\%-a viszont addigra már 50 éves lesz). A 30 milliárd euró költségü Scorpion program első fázisában a haderő VAB, ERC-90 és AMX-10 RC páncélozott harcjárműveit Griffons és Jaguar típusokra cserélik. 2025-ig 35 darab Caesar önjáró löveget is rendszerbe állítanak. A védelmi költségvetési ciklus végétől tervezett második fázisban a VBCI gyalogsági harcjármüvek modernizációja következik, emellett a MAX-56 Leclerc harckocsi utódját Németországgal együttmüködésben fejlesztik. ${ }^{11}$

A haditengerészet modernizációjának részeként a nukleáris rakétákkal felszerelt tengeralattjárók, új hadihajók és üzemanyag-ellátó hajók szolgálatba állítása (4 darab Barracuda osztályú, 8 darab Fremm osztályú és 2 darab FTI osztályú fregatt) elsősorban a tengerentúli területekre irányul. ${ }^{12}$ A jelenleg hadrendben lévő Atlantic 2-t helyettesítő tengeralattjáróvadász repülőgépek beszerzési programját 2020-tól indítanák el, kérdéses azonban, hogy ez egy európai fejlesztési program keretében, vagy az amerikai P8 Poseidonok vásárlásával történne-e. ${ }^{13}$ A tengeri járőrhajók számát 17-ről 19 darabra emelik (ebből 11 új generációs járőrhajó); az egyhéjazatú tartályhajók lecserélését pedig két évvel felgyorsítják.

A légierő modernizációjában a légi utántöltő program és a légi felderítési képességek jelentenek prioritást 2025-ig. Idetartozik az új vadászrepülőgépek (28 darab Rafale F3) beszerzése és a meglévők korszerüsítése (55 darab M200D motor), valamint hogy a légi utántöltő és stratégiai szállító repülőgépek száma 12-ről 15-re nő (az első 12 darab beszerzése a korábbi védelmi költségvetés törvény alapján 2023-ra van ütemezve). ${ }^{14}$ 2017-ben a helikopterflotta 30\%-a volt üzemképes, ez a tervek szerint 2025-re 50\%-ra emelkedne. A képességvesztés megfékezését szolgálja 2018 januárjától a légi képességek müveleti fenntartására megkezdett reformprogram (réforme du MCO aéronautique), ${ }^{15}$ ugyanis az európai

11 Le Programme Scorpion, [online], 2017. 10. 24. Forrás: Defense.gouv.fr [2017. 11. 07.]

12 Képességvesztés abban is jelentkezik, hogy a nyugdíjba vonuló szakértők távozásával csökken a hozzáértő személyi állomány a nukleáris képességek területén. A Barracuda-program Suffren típusú nukleáris meghajtású vadásztengeralattjáróinak fejlesztésében lényeges a lemaradás, ezzel a késéssel a 2030-as harmadik generációs járművek fejlesztéséhez kerül közel, ami viszont segítheti az ipari összekapcsolódásokat. Quelles priorités... i. m.

13 Uo.

14 Az új generációs Rafale vadászrepülőgépek modernizációjának legnagyobb feladata a megfelelő technológiai és digitális képességek rendszeresítése, amelyben elsősorban a biztonságos adatátvitel és (mesterséges intelligencia segítségével) a valós idejü adatfeldolgozás jelenti a kihívást. Uo.

15 A légierő-eszközpark műveleti állapotának fenntartására 2018. január 1-jétől megkezdett reform részeként létrehoznak egy Légierő Karbantartó Igazgatóságot, ami a légi eszközök rendelkezésre állását, harckészültségét felügyeli. Discours de Florence Parly, ministre des Armées, sur le plan de modernisation du Maintien en condition opérationnelle (MCO) aéronautique, [online], 2017. 12. 11. Forrás: Defense.gouv.fr [2018. 02. 01.] 
éghajlatra tervezett, így a sivatagi müveleti környezetben hamar amortizálódó Tigre harci helikopterek karbantartása komoly kihívást jelent. ${ }^{16}$

A képességhiányok pótlása a vezetés-irányítás, kommunikáció, informatikai rendszerek, hírszerzés, felderítés és megfigyelés (C4ISR) képességek területén is kiemelt fontossággal bír. A kiberképességeket a hírszerzés, a védelem és a válaszcsapás területén erősítik. A kibervédelem terén 2019-2025 között 1500 új pozíciót terveznek létrehozni, elérve a 4000 fős kibervédelmi állományt. Az új védelmi költségvetési törvény a ciklusra tervezett 1,6 milliárd eurós kibervédelmi keret mellett az offenzív műveleteket végző „digitális harcosok” jogi helyzetét is rendezi. További prioritás a komplex adathalmazok (big data) feldolgozási képességének erősítése a mesterségesintelligencia-fejlesztést támogató programokkal, valamint a szövetségesek és partnerek, illetve a francia szolgálatok közötti koordináció erősítése. A tengerentúli területeken és azok kizárólagos gazdasági övezeteiben a megfigyelési képességeket járőrhajók telepítésével erősítik. Macron 2018. január 19-i beszédében állandó hírszerzési képesség felállításáról is beszélt, amely a megújított ürszegmens, az új hírszerzési képességek, valamint a MALE RPAS-drónrendszer, a könnyü felderítő repülögépek, elektronikus hadviselési képességek és speciális hírszerzési létesítmények eszközeire támaszkodhat. ${ }^{17}$ Ezek közül számos eszköz az európai partnerekkel való együttmüködésre épül (például az űrszegmens modernizációja és a drónfejlesztés).

3. pillér: A francia stratégiai autonómia megőrzése összekapcsolódik az európai stratégiai autonómia építésének támogatásával. Ebben az európai együttmüködések fejlesztése ipari és müveleti szinten is fontos célkitűzés. Az európai közös fejlesztési programok közül kiemelkedik a következő generációs harci repülőgép (Future Combat Aircraft System - FCAS), az európai drónfejlesztési program (Eurodrones - MALE RPAS) és az új generációs harckocsik (European Main Battle Tank - EMBT) fejlesztése. A védelmi költségvetési törvény megerösíti a folyamatban lévő többnemzeti fejlesztési programokat, így az A400M szállítórepülögépek, NH90 katonai helikopterek, FREMM többcélú fregattok, FSAF légvédelmi rendszer, MUSIS műholdprogram, Tigre helikopterek, ANL/Sea Venom könnyü, hajó elleni rakéták, az MMCM programban a SLAMF tengeri aknamentesítő rendszer ${ }^{18}$ fejlesztését. Továbbá a költségvetési törvény szerint vizsgálják az együttmüködés lehetőségét Olaszországgal a FLOTLOG olajtanker-program és Németországgal a MAST-F rakétaprogram esetében.

Az európai stratégiai autonómia konszolidációját szolgálja a „hajlandó és képes” európai országok körében a közös stratégiai kultúra kialakítása céljából elöterjesztett Európai Beavatkozási Kezdeményezés is. Az európai képességek közös erősítésében Franciaország saját szerepét a magas hozzáadott értékű képességfejlesztésekben hangsúlyozza, amelyek

16 Quelles priorités...i.m.

17 A közepes magasságú, nagy hatótávolságú, pilóta nélküli rendszer (Medium Altitude Long Endurance Remotely Piloted Aircraft System - MALE RPAS) eredetileg Franciaország, Németország és Olaszország kezdeményezésében indított projekt, amely 2016 óta az EDA támogatásával zajlik. A tervek szerint 2025-re valósulna meg az Airbus, a Dassault Aviation és a Leonardo-Finmeccanica közös fejlesztésében. European Male Rpas (Medium Altitude Long Endurance Remotely Piloted Aircraft System) Programme Takes Off, [online], 2016. 09. 28. Forrás: Leonardocompany.com [2017. 11. 01.]

18 A Système de Lutte Anti-Mines Futur (SLAMF) új generációs aknamentesítő rendszer, a brit-francia Maritime Mines Countermeasures képességfejlesztési program része. MMCM - MARITIME MINE COUNTER MEASURES, [online]. Forrás: Occar.int [2017. 11. 01.] 
segítségével a franciák „európai referencia-haderővé” válhatnak, felruházva Párizst azzal a képességgel, hogy egyesítse szövetségeseit a közös stratégiai célok mentén. Ugyanakkor Párizs vezető szerepének hangsúlyozása elsősorban a francia haderő számára fontos üzenet, amely megkönnyítheti a tehermentesítéshez szükséges együttmüködések elfogadását a francia védelmi szféra berkein belül is.

\section{1. táblázat: A föbb francia haditechnikai fejlesztési programok áttekintése}

\begin{tabular}{|c|c|c|}
\hline Kiemelt programok & Lecserélésre kerülő rendszerek & Partnerek \\
\hline $\begin{array}{l}\text { Európai drónfejlesztési } \\
\text { program - MALE RPAS }\end{array}$ & Harafang és Reaper drónok & $\begin{array}{l}\text { Németország, Spanyolország, } \\
\text { Olaszország }\end{array}$ \\
\hline FMAN/FMC hajó elleni rakéták ${ }^{19}$ & Exocet rakéták & Egyesült Királyság (MBDA) \\
\hline $\begin{array}{l}\text { Main Ground Combat System } \\
\text { (MGCS), European Main Battle } \\
\text { Tank (EMBT) „Frankentank” }\end{array}$ & AMX Leclerc harckocsi & Németország (KNDS) \\
\hline $\begin{array}{c}\text { Tengeri járörrendszer PATMAR/ } \\
\text { MAWS }^{20}\end{array}$ & $\begin{array}{l}\text { Atlantique-2 (ATL2 MPA) tengeri } \\
\text { járör repülőgép }\end{array}$ & Németország \\
\hline $\begin{array}{l}\text { FCAS új generációs harci repülőgép } \\
\text { rendszer }\end{array}$ & Rafale & Németország (Airbus, Dassault) \\
\hline
\end{tabular}

Forrás: a szerző szerkesztése

4. pillér: A stratégiai autonómia feltétele az innováció erősítése. A kutatás-fejlesztésre szánt keretet az évi 730 millió euróról 2022-től évi 1 milliárd euróra növelik, ezzel a ciklus alatt összesen 4,6 milliárd eurót fordítanak a robotika, a mesterséges intelligencia, az új fejlesztések energetikai rendszerei, a hipersebességü és lopakodó képességek, valamint a kibervédelem fejlesztéseire. Az innovációra fordított keretben kiemelkedik a mesterséges intelligencia kutatására fordított összeg, amely 1,5 milliárd euró lesz 2019-2025 között. A keretnövelés mellett a Védelmi Technológiai Beszerzési Ügynökség (Direction générale de l’armement - DGA) feladatköre is átalakul, és az ügynökség ezentúl a fegyverrendszerek teljes életciklusára szerződik az ipari szereplőkkel.

A Stratégiai Felülvizsgálat is hangsúlyozta az önálló francia védelmi ipari és technológiai bázis (Base industrielle et technologique de défense - BITD) fenntartásának szükségességét. Ennek kapcsán az elsődleges kihívás egyrészt humán területen jelentkezhet azzal, hogy külföldi, elsősorban amerikai vállalatok elcsábítják a francia mérnököket a francia hadiipari cégektől. Másrészt az európai strukturális kezdeményezések (a 2019-től induló Európai Védelmi Ipari Fejlesztési Terv (European Defense Industrial Development Programme - EDIDP) és az Európai Védelmi Alap (European Defense Fund - EDF) keretében a francia vállalatoknak versenyezniük kell az európai források minél teljesebb körü kiaknázásáért. ${ }^{21}$

Az új francia stratégiai dokumentumok ambícióit olyan dilemmák kísérik, amelyek a következő években is a francia védelmi szféra meghatározó kérdései maradnak. Ilyen

\footnotetext{
19 Futur missile antinavire/Futur missile de croisière (FMAN/FMC), Future Cruise/Anti-Ship Weapon (FC/ASW).

20 Maritime Airborne Warfare System (MAWS).

${ }^{21}$ Quelles priorités...i.m.
} 
összetett kérdés, hogy mennyiben tudják növelni a saját fejlesztéseket, illetve csökkenteni a függést az amerikai technológiától. A Macron által meghirdetett stratégiában a közös európai fejlesztések erősítése fontos célként jelenik meg, de ezzel párhuzamosan az önálló francia védelmi ipari és technológiai bázis védelme és erősítése is megkérdőjelezhetetlen fontosságú, ez a kettősség pedig a következő évek hadiipari folyamataiban is meghatározó marad. További kérdéseket vet fel, hogy az expedíciós (müveleti), illetve a stratégiai (globális) erökivetítési képességek fejlesztése közötti egyensúlyozás hosszú távon mennyire lesz fenntartható. Utóbbi dilemma a francia védelmi ipari bázis fenntartásának szempontjából is figyelemreméltó, mivel az a stratégiai erőkivetítési eszközök fejlesztési képességének megtartását szolgálja. ${ }^{22}$

\section{A francia védelmi költségvetés ütemezése és pénzügyi szabályozása}

Macron a 2018. januári beszédében is megerősítette, hogy 2025-re a nemzeti össztermék 2\%-át fogja elérni a védelmi költségvetés aránya, ami éves szinten körülbelül 50 milliárd eurót jelent. ${ }^{23}$ A 2017-es pénzügyi év 1,79\%-os védelmi költségvetési aránya 2018-ra 1,82\%-ra emelkedett, és 2023-ra elérné az 1,91\%-ot. A védelmi kiadások növelési terve éves bontásban a következóképpen alakul:

\section{2. táblázat: A védelmi kiadások tervezett növelése}

\begin{tabular}{|l|l|l|}
\hline \multicolumn{1}{|c|}{ Év } & \multicolumn{1}{c|}{ Növelés } & \multicolumn{1}{c|}{ Összesen } \\
\hline 2017 & $+0,4$ milliárd euró & 32,4 milliárd euró \\
\hline 2018 & $+1,8$ milliárd euró & 34,2 milliárd euró $(1,82 \%)$ \\
\hline 2019 (következö ciklus) & $+1,7$ milliárd euró & 35,9 milliárd euró \\
\hline 2020 (következő ciklus) & $+1,7$ milliárd euró & 37,6 milliárd euró \\
\hline 2021 (következö ciklus) & $+1,7$ milliárd euró & 39,3 milliárd euró \\
\hline 2022 (következő ciklus) & $+1,7$ milliárd euró & 41 milliárd euró $(1,85 \%)$ \\
\hline 2023 (új elnöki ciklus) & +3 milliárd euró & 44 milliárd euró $(1,91 \%)$ \\
\hline 2024 (új elnöki ciklus) & +3 milliárd euró & 47 milliárd euró \\
\hline 2025 (új elnöki ciklus) & +3 milliárd euró & 50 milliárd euró $(2 \%)$ \\
\hline
\end{tabular}

Forrás: Francia védelmi költségvetési programtörvény, 2019-2025 alapján szerkesztette a szerző ${ }^{24}$

A Macron kampányígéretében szereplő 2\%-os védelmi költségvetés eredetileg nem tartalmazta a nyugdíjakat és a külföldi müveletek költségeinek túlfutását, az új védelmi költségvetési törvényben viszont ezek már a részét képezik a 2025-ig elérni kívánt költségvetési célnak. ${ }^{25}$ A 2023-as évtől kitüzött 3 milliárd eurós éves növelés kapcsán fontos

\footnotetext{
22 Uo.

23 Discours du Président de la République, Emmanuel Macron, vœux aux Armées: i. $m$.

24 Loi de programmation militaire 2019-2025: textes officiels: $i . m$.

25 Defence Expenditure of NATO Countries (2010-2017) [online], 2017. 06. 29. Forrás: nato.int [2018. 03. 07.]
} 
figyelembe venni, hogy 2022 után ez a keretemelés már a következö elnöki ciklusra esik, ami növeli a bizonytalanságot a programtörvény fenntartásával kapcsolatban. A költségvetési törvény ütemezése alapvetően egyenetlen elosztást eredményez a ciklus első és második szakasza között. Ennek részleges magyarázata ugyanakkor az, hogy a nagyszabású beszerzési és fejlesztési programok kiegyenlítési határideje a védelmi költségvetési ciklus végére esik. ${ }^{26}$

A 2024-2025-ös keret pontos összegét 2021-ben határozzák meg egy új felülvizsgálat keretében. Ez az eljárás a törvénytervezet szerint „figyelembe fogja venni az akkori makroökonómiai helyzetet a 2025-re kitüzött 2\%-os cél elérésének teljesítésére vonatkozóan". A francia fiskális fegyelem fenntartása nélkülözhetetlen feltétel a közös európai monetáris és gazdasági reformokról folytatott tárgyalásokban. A 2021-es felülvizsgálati tervezés így alapvetően a francia gazdasági helyzetet és a költségvetési hiány alakulását veszi majd figyelembe a további keretek meghatározásában. ${ }^{27}$ Ugyanakkor e tényezők alapján már az első három év (2019-2021) folyamán is módosíthatják a védelmi költségvetést. A 2017 decemberében elfogadott közfinanszírozási programtörvény szerint ugyanis a védelmi szféra költségvetését minden pénzügyi év esetében megelözi majd az annak újragondolását megengedő költségvetési vita, amelyben a pénzügyminisztérium akarata lesz meghatározó. ${ }^{28}$ Az új védelmi költségvetési törvény továbbá arra kötelezi a védelmi minisztériumot, hogy előbb a fennálló, ki nem fizetett megrendelési tételeit törlessze, mielőtt új tételeket nyitna meg. Ez a gyakorlatban azt jelenti, hogy a 2018-as 34,2 milliárd eurós költségvetésből is 16,9 milliárd euró a korábbi megrendelések törlesztésére irányul. ${ }^{29}$

Habár Franciaországban az elmúlt harminc évben nem került sor hasonló mértékű védelmi kiadásnövelésre, az ütemezés és az intézményi korlátok erősítése jelzi, hogy a francia költségvetési hiány $3 \%$ alatt tartása alapvetően meghatározza majd a védelmi költségvetési törvény integritását és végrehajthatóságát a teljes ciklusban.

26 Érdemes figyelembe venni azonban, hogy korábbi védelmi költségvetési törvények integritása ritkán maradt változatlan a teljes hatéves cikluson át (általában az első két év után felborult az eredeti terv), ugyanis a védelmi költségvetési terv megvalósítása alapvetően a pénzügyminisztérium éves költségvetési iránymutatásától függ, ami figyelmeztető lehet a mostani nagy volumenűnek szánt kezdeményezések értékelésében is. Les orientations choisies par Emmanuel Macron pour les armées sont équilibrées, [online], 2018. 01. 25. Forrás: LeMonde.fr [2018. 03. 07.]

27 2017-ben a francia költségvetési hiány a várt 2,9\%-os GDP-aránynál alacsonyabban alakult, elérve a 2,6\%-ot. Ez 2007 óta az első alkalom, hogy az ország visszatért az európai szerződésekben rögzített 3\%-os küszöb alá. Pourquoi doit-on garder un déficit public inférieur à $3 \%$ du PIB? [online], 2017. 04. 18. Forrás: LeMonde.fr [2018. 03. 07.]

28 LOI n 2018-32 du 22 janvier 2018 de programmation des finances publiques pour les années 2018 à 2022, [online], 2018. 01. 23. Forrás: Legifrance.gouv.fr [2018. 03. 07.]

29 A 2018-as védelmi költségvetésben a hadfelszerelés-beszerzési program 85\%-ban korábbi tételek törlesztésére irányul. LPM: une occasion de repenser en profondeur l'action du ministère des Armées "Les indispensables exigences de la future Loi de programmation militaire: l’ambition des choix”, [online], 2018. 02. 05. Forrás: Ouest-france.fr [2018. 03. 07.] 


\section{Képességfejlesztési arány és irány az előző programtörvény tükrében}

A 2014-es NATO-csúcstalálkozón rögzítették a védelmi kiadások növelésére és a felzárkózásra tett politikai kötelezettségvállalást. ${ }^{30} \mathrm{~A}$ védelmi kiadásokat illetően a NATO költségvetési iránymutatása a képességfejlesztési területet is érinti. Ennek megfelelően a védelmi kiadások $20 \%$-át fegyverrendszerek beszerzésére és kutatás-fejlesztésre kell fordítani, Franciaországot pedig védelmi ipari teljesítménye képessé teszi arra, hogy megfeleljen ennek a követelménynek. ${ }^{31} \mathrm{~A}$ képességfejlesztés aránya a teljes védelmi költségvetésben a 2010-2017-es időszakban is túllépte a 20\%-os modernizációs küszöböt, sőt elérte a $24 \%$-ot. ${ }^{32} \mathrm{Az}$ erre való törekvés az új védelmi költségvetési törvényben is tükröződik, így az összesített müködésfenntartási, beszerzési és fejlesztési keret - a müveleti költségek nélkül - a költségvetési törvény szerint 53\%-ról 63\%-ra emelkedne a ciklus végére (lásd az 1. ábrát).

A Macron-adminisztráció hangsúlyozza, hogy az új védelmi költségvetési törvény elsősorban a meglévő hiányokat orvosolja, amelyek a korábbi évek tartós alulfinanszírozottságának az eredményei. Ugyanakkor a programtörvény folytatólagos abból a szempontból, hogy már Hollande elnöksége (2012-2017) alatt felmerülö kihívások (2015-ös párizsi terrortámadások) hatására 3,8 milliárd euróval emelték a 2014-2019-es védelemköltségvetési törvény alapján rendelkezésre álló összeget. A francia lakosság fenyegetettségpercepciója támogatóan járult hozzá a biztonság- és védelempolitikához kapcsolódó forrásátcsoportosításhoz. Utóbbit támasztja alá a Pew Research 2016-os közvéleménykutatása is: a francia válaszadók 32\%-a növelte, 52\%-a szinten tartotta és csak $14 \%$-a csökkentette volna a védelmi költségvetést. ${ }^{33}$

30 Wales Declaration on the Transatlantic Bond, [online], 2014. 09. 05. Forrás: Nato.int [2018. 03. 07.]; Wales Summit Declaration, [online], 2014. 09. 05. Forrás: Nato.int [2018. 03. 07.]

31 „A védelmi költségvetés belső megoszlását a 40-30-30 százalékos szabályhoz közelítve tekinthetjük »egészségesnek«, amennyiben megfelelő forrásokat kívánunk képességfejlesztésre biztosítani, amelyből $40 \%$ a személyi kiadásokra, 30\% a müködés-fenntartásra, müveletekre, illetve $30 \%$ a fejlesztésre fordítandó." CsıKı Tamás: Hol a pénz? A NATO védelmi kiadási trendjei és a közös teherviselés kérdései, [online], SVKK Elemzések, 2017/2 [2018. 03. 07.]

32 Defence Expenditure of NATO Countries (2010-2017): i. m.

33 Danielle Cuddington: Support for NATO is Widespread Among Member Nations, [online], 2016. 07. 06. Forrás: PEW Research [2018.03.07.] 


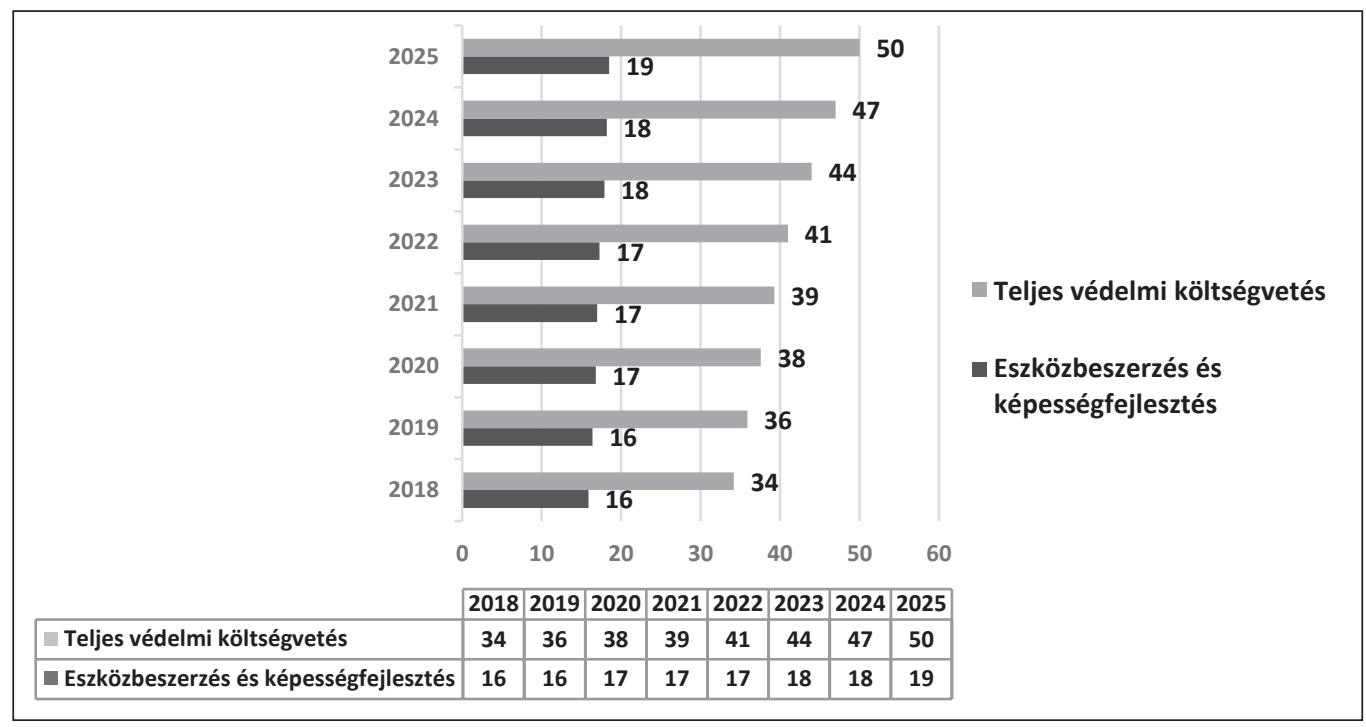

\section{1. ábra: Az eszközbeszerzési és képességfejlesztési tételek tervezett aránya a francia védelmi költségvetésben 2018-2025 között (milliárd euró)}

Forrás: Francia költségvetési programtörvény, 2019-2024 alapján szerkesztette a szerzö ${ }^{34}$

Az új programtörvény a 2014-2019-es védelmi költségvetés által meghatározott irányokhoz illeszkedik, amely a 2013-as Fehér könyvben kijelölt célokon alapult. ${ }^{35}$ A 2014-2019-es költségvetési törvényhez ugyanis - mint fent már jeleztük - számos beszerzési és fejlesztési program kötődik. A 2014-2019-es ciklusban indultak az FCAS fejlesztései brit együttmüködésben, a MALE RPAS drón, az új generációs hajó elleni rakéták, új generációs aknamentesítő rendszer, valamint a haditengerészeti logisztikai programok. A 2019-2025-ös védelmiköltségvetési-törvény a csúszások következtében nagyrészt a fennálló megrendelések beszerzési folyamatát zárja le, amelyeket eredetileg a 2014-2019-es periódus végéig kellett volna teljesíteni. ${ }^{36}$

Szintén már a 2014-2019-es ciklusban megjelent a két komponensủ nukleáris elrettentés (légierő és haditengerészet) megújításának előkészítése. Ebben az időszakban ugyanakkor a stratégiai erőkivetítési rendszerek kevesebb figyelmet kaptak. Helyettük az aszimmetrikus hadviselési képességek erősítése került a középpontba, úgymint a páncélozott harcjármüvek védelme, a kommunikációs (COMINT) és képalkotó hírszerzés (IMINT) fejlesztését előkészítő programok, a képi feldolgozás, az elektronikai hadviselés, a hírszerzési elemzés, a műveleti digitalizáció és a rádiónavigációs rendszerek. Az improvizált robbanóeszközök ellen a gyalogsági harcjárművek (VBCI-2) védelme, a harci drónok, MALE

\footnotetext{
34 “Agrégat Equipement”, Rapport Annexé, Loi de programmation militaire 2019-2025: textes officiels, [online], 2018. 02.16. Forrás: Defense.gouv.fr [2018. 03.07.]

35 Actualisation de la loi de programmation militaire (LPM) 2014-2019, [online], 2016. 06. 10. Forrás: Defense.gouv.fr [2018. 03. 07.]; Le Livre blanc 2013 rendu public, [online], 2013. 07. 15. Forrás: Defense.gouv.fr [2018. 03. 07.]

36 LPM: une occasion de repenser en profondeur l'action du ministère des Armées... i.m.
} 
drónok, valamint a hírszerzési képességek fejlesztése vált kiemeltté. ${ }^{37}$ A 2019-2025-ös védelmiköltségvetési-törvény ugyanakkor már a stratégiai erőkivetítési képességek fejlesztését is hangsúlyozza a teljes spektrumú haderőfejlesztési modell keretein belül.

\section{A múveletek terhe}

Jelenleg Franciaország (a tartalékosokat is beleértve) megközelítőleg 30 ezer föt állomásoztat különböző müveletekben és tengerentúli támaszpontokon. A francia műveletek távlatait alapvetően meghatározza a műveleti fáradtság problémája. A müveleti vállalások túlfutása komoly nehézség a fenntarthatóság (azaz a müveleti támogatás és kiképzés biztosítása) kapcsán. A kihívás abban jelentkezik, hogy hogyan lehet a rugalmasságot erősíteni egy olyan állapotban, amikor a folyamatban lévő túlfutott müveletek lekötik a haderőt. ${ }^{38}$ A helyzet súlyosságát jelzi, hogy 2017. szeptember 4-én François Lecointre vezérkar főnök felvetette egy kvázi műveleti szünet lehetőségét, amely alatt a francia haderő feltöltődhetne és felkészülhetne a jövő vállalásaira. Ezt az ötletet azonban sem a felülvizsgált stratégiában, sem más hivatalos fórumokon nem erősítették meg. ${ }^{39}$ A Hollande elnöksége alatt megkezdett és jelenleg is aktív Sentinelle belföldi terrorellenes müvelet terhe hozzáadódott a nagyszabású külföldi müveletek kihívásaihoz. A francia haderőnek így a képességek és a személyi állomány túlfeszítettségével kell szembenéznie, annak ellenére, hogy a 2014-2019-es költségvetési ciklus keretét 2016-ban 3,8 milliárd euróval megemelték. Ezt az emelést ugyanakkor annak fényében érdemes értelmezni, hogy a 2014-2019-es védelmi tervezési költségvetési törvény keretei létszám- és képességcsökkentést jelentettek a haderő számára a megelőző ciklushoz képest. ${ }^{40}$

\section{3. táblázat: A folyamatban lévő föbb francia, illetve francia részvétellel zajló müveletek}

\begin{tabular}{|l|l|}
\hline \multicolumn{1}{|c|}{ Müveletek } & \multicolumn{1}{c|}{ Földrajzi fókusz és a müvelet indításának idöpontja } \\
\hline Sentinelle (10 000 fó) & Franciaország (2015. január) \\
\hline Barkhane (4500 fö) & Száhel-övezet, Észak Afrika (2014. június) \\
\hline Chammale (1200 fö) & Közel-Kelet (2014. szeptember Irak; 2015. szeptember Szíria) \\
\hline Corymbe (250 fö) & Guineai-öböl (1990-töl) \\
\hline Sophia (EUNAVFOR MED) (1000 fö) & Földközi-tenger (2015. június) \\
\hline Atalanta (EU) (200 fó) & Indiai-óceán (2008. december) \\
\hline UNIFIL (ENSZ) (900 fó) & Libanon (2006) \\
\hline Lynx (NATO EFP) (300 fó) & Baltikum (2017) \\
\hline
\end{tabular}

Forrás: Ministère des Armées, Opérations, [online]. Forrás: Defense.gouv.fr

2018. 03. 07. alapján szerkesztette a szerző

37 Quelles priorités...i. $m$.

38 A 2013-as fehér könyv 30\%-os műveleti túlfutási időt hagyott jóvá, ezt már meghaladják a jelenleg folyamatban lévő müveletek.

39 Vincent Lamigeon: Le chef d’état-major des armées dézingue la „régulation budgétaire sauvage” de Bercy, [online], 2017. 09. 05. Forrás: Challenges.fr [2017. 11. 01.]

40 A 2013-as fehér könyv alapján 1,9\%-ról 1,76\%-ra csökkent a GDP-arányos védelmi költségvetés. A 280 ezer fős állományt eredetileg 34 ezer fóvel csökkentették volna a 2016-2019-es időszakban, azonban ezt módosították a 2015-ös események kapcsán hozott kiegészítő intézkedések. Projet de loi de finances pour 2017: Défense: préparation et emploi des forces, [online], 2016. 11. 24. Forrás: Sénat.fr [2017. 11. 01.] 
Amíg a legnagyobb volumenü, beföldön zajló, terrorellenes Sentinelle műveletnek az állomány kimerülésének kihívásával kell szembenéznie, addig a külföldi müveletek elsősorban a támogató képességek fenntartásával és a műveleti eszközök amortizációjával küzdenek. A Macron elnök által elfogadott intézkedések ezt a müveleti költségvetési keret, a műveleti átstrukturálás, a külföldi műveleti ambíciószint, illetve az alternatív együttmüködések segítségével igyekeznek kezelni.

\section{A müveleti költségvetési keret}

A müveletek fenntarthatósága érdekében a 2018-as pénzügyi évre vonatkozó költségvetésben emelkedett a külföldi műveletekre szánt összeg. A 2017-ben 450 millió eurós keret 2018-ban 650 millió euróra nőtt. ${ }^{41}$ A tervek alapján ez az összeg 2020-ra elérné az évi 1,1 milliárd eurót. Habár a bejelentett keretnövelés Macron szerint a „korábbi évek külföldi müveleteinek szisztematikus alulfinanszírozottságát" hivatott kiegyensúlyozni, rövid távon (2018-2019) azonban csupán részlegesen korrigálja a 2017-es védelmi költségvetési megszorítások következtében kialakult helyzetet. A haderö és az elnök kapcsolatát 2017 nyarán beárnyékoló védelmiköltségvetési-dráma Villers vezérkar főnök lemondásához vezetett. ${ }^{42}$ A 2014-2019-es programtörvény eredeti keretét 2016-ról 2017-re 600 millió euróval növelték. Az így elért 32,7 milliárd eurót (GDP 1,77\%) a kormányzati megszorítások miatt ugyanakkor az év közepén 850 millió euróval csökkentették. A megszorítás következtében a védelmi tárcának kellett a Sentinelle művelet és a külföldi műveletek túlköltéseire (összesen 1,3 milliárd euró) forrást találnia, amellett, hogy a költségvetésében további 700 millió eurót befagyasztottak. ${ }^{43}$

$\mathrm{Az}$ új vezérkari fönöknek kinevezett Lecointre tábornok a felülvizsgálati stratégia és a védelmi költségvetés kapcsán előzetesen azt nyilatkozta, kockázatos azt állítani, hogy a védelmi minisztérium képes a külföldi műveletek költségét fedezni a jövőben is (mint ahogy azt a 2017-es költségcsökkentés nyomán biztosítaniuk kellett), helyette a közös költségvetés elve alapján a tárcák között megosztott felelösségvállalást támogatja. ${ }^{44} \mathrm{Az}$ új vezérkar fonnök azt is kifejtette, hogy a francia fegyveres erők „funkciójuk alapján felelősek az általános koherencia megvalósulásáért mind a védelmi tervezés, mind költségvetés oldaláról". A felülvizsgált stratégia ugyanakkor nyomatékosan hangsúlyozta, hogy a katonai stratégiával kapcsolatos döntési jogkör az elnök kezében van. ${ }^{45}$

${ }^{41}$ A külföldi műveletek keretének növelése (200 millió euróval) már 2015-ben felmerült egy parlamenti javaslatként. Lásd: Vincent KRANEN: OPEX: un rapport parlementaire veut consacrer 200 millions deuros par an au renouvellement du matériel militaire, [online], 2015. 12. 15. Forrás: Lcp.fr [2018. 04. 01.]

42 A védelmi költségvetést érintő megszorításokat kritizáló Villers volt vezérkari fönök megnyilatkozása kapcsán Macron úgy fogalmazott, hogy az elnök és a vezérkari fönök szembenállása esetén a vezérkari fönöknek kell távoznia, aki ezt követően, 2017. július 19-én le is mondott posztjáról. Macron megjegyzése a hadsereg körében erős visszatetszést váltott ki, és a hadsereg, valamint az elnök közötti bizalom jelentősen gyengült. Démission de Pierre de Villiers: pour le général Desportes, la confiance entre les armées et le président „est rompue”, [online], 2017. 07. 19. Forrás: Europe1.fr. [2017. 11. 05.]

43 Chiffres clés de la Défense - 2017: i. m. Vincent Lamigeon: Budget des armées 2017: un défi kafkaien, [online], 2017. 07. 21. Forrás: Challenges.fr [2017. 11. 04.]

44 LAMIgEON: Le chef détat-major des armées dézingue la „régulation budgétaire sauvage” de Bercy: i. $m$.

45 Az elnök döntési jogkörét a stratégiai irány meghatározásával kapcsolatban hatszor hangsúlyozza a Stratégiai Felülvizsgálat. Revue Stratégique De Défense Et De Sécurité Nationale, [online], 2017. Forrás: Defense.gouv.fr [2017. 10. 15.] 
4. táblázat: A külföldi müveletekre szánt költségkeret a francia védelmi kiadásokon belül 2017-2023 között

\begin{tabular}{|c|c|c|c|c|c|c|c|}
\hline Év & 2017 & 2018 & 2019 & 2020 & 2021 & 2022 & 2023 \\
\hline Millió euró & 450 & 650 & 850 & 1100 & 1100 & 1100 & 1100 \\
\hline
\end{tabular}

Forrás: Loi de Programmation Militaire 2019-2025, Rapport Annexé alapján szerkesztette a szerző

A müveletekre szánt fokozatos keretemelés kapcsán fontos észrevétel, hogy az emeléssel párhuzamosan a műveleti költségek túlfutása teljes mértékben a védelmi szférát terheli majd. A védelmi költségvetési törvény szerint a védelmi minisztérium 1,1 milliárd eurós költségig lesz felelős a túlköltések megtérítéséért, amelyeket a korábbi években a központi költségvetésből fedeztek.

\section{Átstrukturálás és ambíciószint a képességek tükrében}

A költségvetési keret biztosításán túl a műveleti fáradtság kezelése operatív szinten a műveletek átstrukturálásában, stratégiai szinten pedig a külföldi műveletekre vonatkozó ambíciószint meghatározásában is megjelenik. 2017. szeptember 14-én módosították a Sentinelle művelet alkalmazási doktrínáját. A müvelet mandátuma továbbra is azonos marad, de az eredetileg 7000 fős, kötött szolgálati helyen alkalmazott aktív állomány és 3000 tartalékos rendszerét újrastrukturálták és a prefektusi lánc irányítása alá rendelték. Az átalakítás változtat a járőrszolgálat-tartalék felosztáson: az aktív állomány fele ( 3500 fö) továbbra is helyhez kötött szolgálatot teljesít, amíg a további 3500 fö az igényeknek megfelelően rugalmasabb rendszerben mobilizálható. Így a megújított művelet szerkezete három részből áll: az állandó műveleti bázis a legsebezhetőbb helyek védelméért felel; a kiszámíthatatlan járőrözési rendszer és „fokozatos készenléti szint” az alkalmi és szezonális események biztosítására jelent erősítést; a 3000 fős stratégiai tartalék pedig a váratlan válsághelyzetekben áll a köztársaság rendelkezésére. ${ }^{46} \mathrm{Ez}$ a változtatás több lehetőséget hagy a kiképzésre és a stratégiaitartalék-képzésre. ${ }^{47}$ A Sentinelle müvelet kapcsán az állomány alacsony színvonalú elszállásolása, a családok minimális kompenzációval járó és gyakran váratlan áthelyezése a katonák növekvő kiábrándultságával és megszaporodott seregelhagyással járt, további humánerőforrás-problémát okozva a stratégiai fáradtsággal küszködő szervezetben. A mo-

46 Florence Parly annonce les grands chantiers du ministère des Armées, [online], 2017. 09. 14. Forrás: Defense.gouv.fr [2017. 11.01.]

Nathalie Guibert: Le gouvernement veut faire évoluer la mission Sentinelle de sécurisation par l’armée, [online], 2017. 09. 15. Forrás: LeMonde.fr [2017. 11. 01.]

47 Uo. 
rál javítását szolgálta a védelmi miniszter októberi ígérete, miszerint a következő öt évben 300 millió eurót terveznek a katonák és katonacsaládok környezeti és lakhatási körülményeinek javítására fordítani. ${ }^{48}$

Az átstrukturálás és a moráljavítás mellett a haderő hazai müveleti képességeit erősítik a városi mobilitást segítő eszközök fejlesztésével, továbbá az egyéni felszerelések pótlásával is (lásd a haderőfejlesztés 1. pillérét). Emellett már a 2018-as pénzügyi év védelmi költségvetésében hangsúlyt kapott a hazai müveletet kiegészítő biztonsági intézkedések erősítése, így a katonai és közösségi létesítmények (például az üzemanyag- és hadianyagraktárak, iskolák, kórházak) biztosítása, valamint 150 új biztonsági pozíció (őrző-védő feladatokra) és egy 105 millió eurós infrastruktúravédelmi fejlesztési keret (például passzív védelem, videómegfigyelés) a Védelmi Minisztérium szervezeti keretén belül. ${ }^{49}$

A külföldi müveletekre (opérations extérieures - Opex) vonatkozó ambíciószintet a Stratégiai Felülvizsgálat egy időben három hadszíntérben állapította meg. A francia haderőnek képesnek kell lennie egy müveletben önállóan, egy müveletben keretnemzeti szerepben, egy műveletben pedig fö hozzájáruló partnerként cselekedni. ${ }^{50}$ Ehhez az ambíciószinthez csak korlátozott képességnövelés társul a 2019-2025-ös védelmi költségvetési törvény alapján. A külföldi müveletekben alkalmazott vadászrepülőgépek számát 12-ről 14-re emelik - ehhez képest az elmúlt évek legintenzívebb müveleti szakaszaiban több mint 20 repülőgépet alkalmaztak. A fegyveres erők készenlétének fenntartása kapcsán az eszközök élettartamának meghosszabbítása előnyt élvez az új eszközök beszerzésével szemben. Ez nagy elvárásokat támaszt a karbantartó programokkal szemben, ugyanakkor nem határoztak meg célmennyiséget vagy céldátumot az eszközök felújítására vonatkozóan. A karbantartó programok különösen fontosak a légierő képességmegőrzése kapcsán, hiszen az európai éghajlatra tervezett eszközök nem bírják a sivatagi környezet amortizáló hatását. ${ }^{51}$

A műveleti ambíciószint meghatározása és a műveleti képességek megújítása mellett az aktív külföldi müveletek fokozatos átstrukturálása is folyamatos feladat Franciaország számára. 2017 júliusa és 2018 májusa között a Szíria és Irak területére irányuló Chammal müveletben telepített katonák száma 1200-ról 1100-ra, ugyanebben az időszakban a libanoni Daman müveletben a katonák száma 900-ról 700-ra csökkent. ${ }^{52} 2017$ decemberében Florence Parly védelmi miniszter két Rafale vadászgép kivonását jelentette be a Chammal müveletből. ${ }^{53}$ Parly szerint a müveletek szárazföldi része véget ért a Közel-Keleten, így bár a szíriai területeken továbbra is számítanak fegyveres harcokra, az iraki területeken

\footnotetext{
48 Alonso: $i$. $m$.

49 Le budget du ministère des Armées pour 2018, [online]. Forrás: Gouvernement.fr [2018. 01. 25.]

50 A Száhel-övezetben a Barkhane az önálló, a Közel-Keleten a Chammal a koalíciós, Libanonban az UNIFIL-misszió pedig a hozzájáruló szerepnek feleltethető meg. A 2013-as fehér könyvben alacsonyabb ambíciószint szerepel: „két-vagy három hadszíntér, amely közül egyben fő hozzájárulóként van jelen”. Az elhúzódó műveleti élettartam kapcsán kiemelt szempont a fenntarthatóság, aminek kapcsán a 2017-es Felülvizsgált Stratégia a müveleti élettartamot 10-15 évben határozta meg.

${ }^{51}$ Michel CABIRol: Les cinq graves vulnérabilités qui pèsent sur la future loi de programmation militaire, [online], 2018. 02. 09 Forrás: Latribune.fr [2018. 03. 01.]

52 Opération Chammal, [online], 2018. 06. 14. Forrás: Defense.gouv.fr [2018. 06. 14.]; Daman: la contribution française à la FINUL, [online], 2018. 03. 14. Forrás: Defense.gouv.fr [2018. 05. 19.]

${ }_{53}$ La France réduit son dispositif militaire en Irak et en Syrie, [online], 2017. 12. 29. Forrás: Europe1.fr [2018. 03. 01.]
} 
a stabilizációs és újjáépítési feladatok kerülnek előtérbe. ${ }^{54}$ A 2017 . augusztusi francia miniszteri látogatás keretében megközelítőleg 430 millió eurós kölcsön folyósítását jelentették be az iraki kormány részére. ${ }^{55} \mathrm{~A}$ Chammal művelet intenzitásának csökkenésével párhuzamosan 2017 júliusa és 2018 májusa között ugyanakkor az észak-afrikai Barkhane müveletben telepített katonák száma 4000-ről 4500-ra, a logisztikai jármüvek száma 300-ról 360-ra, a páncélozott gépjármúvek száma pedig 300-ról 470-re nőtt. ${ }^{56}$

\section{Az alternatív együttmüködések kialakitása és partnerek bevonása}

A DGAP német kutatóközpont elemzése szerint a francia müveleti fáradtságot jelzi, hogy Párizs képes egyedül elindítani müveleteket, de már nem képes egyedül befejezni őket. ${ }^{57}$ Ezt a gondolatot támasztja alá, hogy a Száhel-övezet kimerítő műveleti követelményei (hatalmas távolságok; a katonai eszközök gyors amortizációja; magas üzemanyagköltségek) fenntarthatósági szempontból komoly kihívást jelentenek Franciaország számára, ennek terhét és felelősségét pedig szövetségeseik további bevonásával szeretnék csökkenteni. Az Egyesült Királyság a 2018. január 17-i sandhursti brit-francia csúcstalálkozón jelentette be a Barkhane müvelet támogatását három $\mathrm{CH}-47$ Chinook szállítóhelikopterrel, ami szintén azt igazolja, hogy a francia erők elsősorban logisztikai képességek terén igénylik partnereik támogatását. ${ }^{58}$ Párizs továbbá kiemelt jelentőséget tulajdonít a G5 Száhel-erőknek, ami a francia remények szerint a Barkhane müvelet tehermentesítését segíthetné. A 2017. július 3-án életre hívott G5 Száhel-erők, azaz a Niger, Mali, Burkina Faso, Mauritánia és Csád együttmüködésében szervezett, 5000 fős többnemzeti terrorellenes katonai erőnek a tervek szerint 2018 nyarán kellene elérnie a teljes műveleti készenlétet. A kezdeményezés fenntartása ugyanakkor folyamatos külső támogatást igényel (és az elvárásoknak ezek birtokában sem képes teljes mértékben megfelelni). ${ }^{59}$ Franciaország aktívan és sikerrel lobbizott szövetségeseinél a kezdeményezés finanszírozása és a régióba irányuló fejlesztési segélyezés

54 La loi de programmation militaire en passe d’être arbitrée, [online], 2018. 01. 16. Forrás: Fr.reuters.com [2018. 03. 01.]

552014 és 2017 között 70 millió euró francia humanitárius és stabilizációs segély érkezett Irakba, ebből 35 millió 2017 -ben. Irak - Q\&R - Extrait du point de presse (11 décembre 2017), [online], 2017. 12. 11. Forrás: Diplomatie.gouv.fr [2018. 03. 01.]

56 Opération Barkhane, [online], 2018. 06. 19. Forrás: Defense.gouv.fr [2018. 06. 19.]

57 Claudia Major - Christian MöLling: Pragmatisch und europäisch: Frankreich setzt neue Ziele in der Verteidigungspolitik, [online], 2017. Forrás: Dgap.org [2017. 11.01.]

58 Az Egyesült Királyság 3 CH-47 Chinook szállítóhelikoptert és az üzemeltetésükhöz szükséges személyzetet (50-60 fö) telepít Maliba a Barkhane művelet támogatására. Az Egyesült Királyság eddig is támogatta a Száhel-övezetben folyó terrorellenes harcokat a RAF stratégiai szállító repülőgépeivel, a mali ENSZ-missziót és a nigériai fegyveres erőket pedig katonai kiképzésekkel. UK and France commit to new defence cooperation, [online], 2018. 01. 18. Forrás: Gov.uk [2018. 03. 01.]

592018 februárjában az EU, az ENSZ, az Afrikai Unió és a G5 Száhel-csoport társelnöksége alatt rendezett konferencián 414 millió euró támogatásról döntöttek a G5 Száhel-erők részére. Ebből az Európai Unió - az eredeti hozzájárulását megduplázva - 100 millió euróval támogatja a kezdeményezést. A részt vevő afrikai államok egyenként 10 millió eurót (összesen körülbelül 50 millió eurót), Szaúd-Arábia 100 millió eurót, az Egyesült Arab Emírségek 30 millió eurót, Franciaország 9 millió eurót, Hollandia 5 millió eurót ajánlott fel. A G5 Száhel-csoport soros elnökségét ellátó nigériai Issoufou elnök szerint a Száhel-erők fenntartása a kezdeti támogatás összegén túl éves szinten 115 millió eurót igényelne a következő időszakban. West African and French leaders launch Sahel force, [online], 2017. 07. 03. Forrás: Aljazeera. com. [2017. 11. 01.]; EU mobilises the international community for Africa's Sahel region, [online], 2018. 02. 23. Forrás: Ec.europa.eu [2018. 03. 23.]; Andrew Lebovich: G5 Sahel: Much done, more to do, [online], 2018. 03. 08. Forrás: Ecfr. eu [2018. 03. 23.] 
növelése érdekében, így az Európai Unió felajánlásának biztosítása mellett Németországtól és az Egyesült Államoktól is sikerült támogatást szereznie. ${ }^{60}$

A müveleti együttmüködések hangsúlya a Barkhane müvelet és a Száhel-erők gyakorlati támogatásán túl más kezdeményezésekben is megjelenik. Macron januári beszédében hangsúlyozta egy „közös prevenciós stratégia” kialakításának szükségességét az európai partnerekkel, amely a régió Európára is hatást gyakorló biztonsági kihívásait lokálisan kezelheti. Macron elképzelése szerint továbbá a francia müveletek európai erőket fogadnának katonai müveleti partnerségek keretében, ami az afrikai békefenntartó képességek erősítését egészítheti ki az állomány feltöltésének támogatásával.

Franciaországot a műveleti tehermentesítés alternatívái erősen foglalkoztatják, így a műveleti átstrukturálás és a korlátozott költségvetési keretek emelése mellett a partnerek bevonásán alapuló tehermegosztás is a francia müveletek stabilizálásának fontos eszközeivé vált.

\section{Összegzés és következtetések}

A Macron elnök támogatásával elkészített 2019-2025-ös védelmi költségvetési törvény és az irányadó Stratégiai Felülvizsgálat tervezését alapvetően meghatározták a normatív francia tradíciók, a műveleti túlterheltség és a haderőfejlesztés 2030-as ambíciószintje. Macron elnök a nukleáris elrettentési képesség (force de frappe) modernizálásáról született döntését a gaulle-ista („indépendance”) hagyomány örökségével is indokolta, amely Franciaország globális hatalmi szerepének biztosítását is szolgálja. Az elmúlt évek müveleti terhei a műveleti képességek megújítását is létfontosságúvá tették mind a személyi állomány, mind pedig az eszközök karbantartása szintjén. A költségvetési törvény folytatólagosságot mutat a Hollande elnök alatt megkezdett fejlesztési és beszerzési programok befejezését illetően, míg a haderő 2030-as ambíciószintjének (új repülőgép-hordozó, új generációs harckocsi és vadászrepülőgép) megvalósítását az innováció fokozatos erősítésével támogatja. A 2\%-os GDP-célarány a védelmi költségvetés fokozatos növelését irányozza elö 2025-ig.

Macron stratégiája a teljes spektrumú haderő koncepcióját hangsúlyozza, amelyben egyaránt fontos mindegyik haderőnem fejlesztése. Ez az ambiciózus vállalkozás bonyolult egyensúlyozással egyszerre választja a nukleáris elrettentés erősítését és a konvencionális eszközök modernizálását. A védelmi költségvetési keret konszenzusos elosztást tükröz, amely hierarchikus rendezőelv nélkül minden haderőnem igényét igyekszik figyelembe venni. Kérdés marad ugyanakkor, hogy ez a stratégia mennyire bizonyul ellenállónak a strukturális reformok és a müveleti fáradtság nyomása alatt. Habár a francia védelmi

60 Párizs növelte a régióba irányuló fejlesztési segélyezés összegét, így a következő öt évben összesen 1,2 milliárd eurót irányít a térségbe, továbbá a l'Alliance Sahel fejlesztési segélyezési kezdeményezésében igyekszik szövetségeseseinek hozzájárulását is koordinálni. Az Egyesült Államok 2017 októberében 60 millió dollár (45 millió euró) bilaterális segélyt ajánlott fel. Németország szerepvállalását a MINUSMA, EUTM Mali, G5 Száhel műveletek támogatásában és a régióba irányuló segélyezés kapcsán is kiemelten értékelte a francia felülvizsgálati stratégia. United States Pledging up to $\$ 60$ Million in New Support for Security Assistance in the Sahel Region, [online], 2017. 10. 20. Forrás: State.gov [2017. 11. 01.]; La force conjointe G5 Sahel et l'Alliance Sahel, [online], 2018. 03. 01. Forrás: Diplomatie.gouv.fr [2018. 03. 23.] 
szférát a közvélemény is támogatja, a francia gazdaság teljesítménye meghatározó korlát marad a szerteágazó védelmi ambíciók költséges támogatása előtt.

\section{FELHASZNÁLT IRODALOM}

"Agrégat Equipement", Rapport Annexé, Loi de programmation militaire 2019-2025: textes officiels, [online], 2018. 02. 16. Forrás: Defense.gouv.fr [2018. 03. 07.]

Les orientations choisies par Emmanuel Macron pour les armées sont équilibrées, [online], 2018. 01. 25. Forrás: Lemonde.fr [2018. 03. 07.]

Actualisation de la loi de programmation militaire (LPM) 2014-2019, [online], 2016. 06. 10. Forrás: Defense. gouv.fr [2018. 03. 07.]

Alonso, Pierre: La ministre des Armées veut améliorer le quotidien des militaires, [online], 2017. 10. 31. Forrás: Liberation.fr [2017. 11. 07.]

CABIROL, Michel: Les cinq graves vulnérabilités qui pèsent sur la future loi de programmation militaire, [online], 2018. 02. 09. Forrás: Latribune.fr [2018. 03. 01.]

Cuddington, Danielle: Support for NATO is Widespread Among Member Nations, [online], 2016. 07. 06. Forrás: PEW Research [2018. 03. 07.]

CsIKI Tamás: Hol a pénz? A NATO védelmi kiadási trendjei és a közös teherviselés kérdései, [online], SVKK Elemzések, 2017/2 [2018. 03. 07.]

Defence Expenditure of NATO Countries (2010-2017), [online], 2017. 06. 29. Forrás: Nato.int [2018. 03. 07.]

Défense: «Nos armées doivent acquérir plus rapidement leurs équipements opérationnels», [online], 2018. 03. 27. Forrás: Lemonde.fr [2018. 04. 01.]

Démission de Pierre de Villiers: pour le général Desportes, la confiance entre les armées et le président „est rompue", [online], 2017. 07. 19. Forrás: Europe1.fr. [2017. 11. 05.]

Discours de Florence Parly, ministre des Armées, sur le plan de modernisation du Maintien en condition opérationnelle (MCO) aéronautique, [online], 2017. 12. 11. Forrás: Defense.gouv.fr [2018. 02. 01.]

Discours du Président de la République, Emmanuel Macron, vœux aux Armées, [online], 2018. 01. 23. Forrás: Elysee.fr [2018. 03. 01.]

EU mobilises the international community for Africa’s Sahel region, [online], 2018. 02. 23. Forrás: Ec.europa. eu [2018. 03. 23.]

European Male Rpas (Medium Altitude Long Endurance Remotely Piloted Aircraft System) Programme Takes Off, [online], 2016. 09. 28. Forrás: Leonardocompany.com [2017. 11. 01.]

Florence Parly annonce les grands chantiers du ministère des Armées, [online], 2017. 09. 14. Forrás: Defense. gouv.fr [2017. 11.01.]

Florence Parly présente le Plan d'accompagnement des familles et d'amélioration des conditions de vie des militaires 2018-2022, [online], 2017. 10. 31. Forrás: Defense.gouv.fr [2017. 11. 07.]

GUIBERT, Nathalie: Le gouvernement veut faire évoluer la mission Sentinelle de sécurisation par l'armée, [online], 2017. 09. 15. Forrás: LeMonde.fr [2017. 11. 01.]

Initiative pour l'Europe - Discours d'Emmanuel Macron pour une Europe souveraine, unie, démocratique, [online], 2017. 09. 26. Forrás: Elysee.fr [2017. 11. 07.]

Irak - Q\&R - Extrait du point de presse (11 décembre 2017), [online], 2017. 12. 11. Forrás: Diplomatie.gouv. fr [2018. 03. 01.]

KRANEN, Vincent: OPEX: un rapport parlementaire veut consacrer 200 millions d'euros par an au renouvellement du matériel militaire, [online], 2015. 12. 15. Forrás: Lcp.fr [2018. 04. 01.] DOI: https://doi. org/10.4414/pc-f.2015.00995

La force conjointe G5 Sahel et l'Alliance Sahel, [online], 2018. 03. 01. Forrás: Diplomatie.gouv.fr [2018. 03. 23]

La France réduit son dispositif militaire en Irak et en Syrie, [online], 2017. 12. 29. Forrás: Europe1.fr [2018. 03. 01.] 
La loi de programmation militaire en passe dêtre arbitrée, [online], 2018. 01. 16. Forrás: Fr.reuters.com [2018. 03. 01.]

La loi renforçant la sécurité intérieure et la lutte contre le terrorisme (SILT)Décret n² 2017-1095, [online], 2017. 06. 14. Forrás: Legifrance.gouv.fr [2018. 03. 01.]

LAmigeon, Vincent: Budget des armées 2017: un défi kafkaien, [online], 2017. 07. 21. Forrás: Challenges.fr [2017. 11.04.]

LAMIGEON, Vincent: Le chef détat-major des armées dézingue la „régulation budgétaire sauvage” de Bercy, [online], 2017. 09. 05. Forrás: Challenges.fr [2017. 11. 05.]

Le budget du ministère des Armées pour 2018, [online]. Forrás: Gouvernement.fr [2018. 01. 25.]

Le Livre blanc 2013 rendu public, [online], 2013. 07. 15. Forrás: Defense.gouv.fr [2018. 03. 07.]

Le Programme Scorpion, [online], 2017. 10. 24. Forrás: Defense.gouv.fr [2017. 11. 07.]

Lebovich, Andrew: G5 Sahel: Much done, more to do, [online], 2018. 03. 08. Forrás: Ecfr.eu [2018. 03. 23.]

Loi de programmation militaire 2019-2025: textes officiels, [online], 2018. 02. 16. Forrás: Defense.gouv.fr [2018. 03.07.]

LOI nº 2018-32 du 22 janvier 2018 de programmation des finances publiques pour les années 2018 à 2022, [online], 2018. 01. 23. Forrás: Legifrance.gouv.fr [2018. 03. 07.]

LPM: une occasion de repenser en profondeur l'action du ministère des Armées "Les indispensables exigences de la future Loi de programmation militaire: l'ambition des choix”, [online], 2018. 02. 05. Forrás: Ouest-france.fr [2018. 03. 07.]

Major, Claudia - MölLing, Christian: Pragmatisch und europäisch: Frankreich setzt neue Ziele in der Verteidigungspolitik, [online], 2017. Forrás: Dgap.org [2017. 11. 01.]

Chiffres clés de la Défense - 2017, [online], 2017. Forrás: Defense.gouv.fr [2017. 11. 01.]

Ministère des Armées, Opérations, [online]. Forrás: Defense.gouv.fr [2018. 03. 07.]

MMCM - MARITIME MINE COUNTER MEASURES, [online]. Forrás: Occar.int [2017. 11. 01.]

NÁDUdVARI Anna: A 2017-es francia stratégiai felülvizsgálat értékelése, [online], Nemzet és Biztonság, 11. évf., 2018/3. 55-78. o.

Opération Barkhane, [online], 2018. 06. 19. Forrás: Defense.gouv.fr [2018. 06. 19.] DOI: https://doi. org/10.5965/1984723819392018006

Opération Chammal, [online], 2018. 06. 14. Forrás: Defense.gouv.fr [2018. 06. 14.]

Daman: la contribution française à la FINUL, [online], 2018. 03. 14. Forrás: Defense.gouv.fr [2018. 05. 19.]

Pourquoi doit-on garder un déficit public inférieur à $3 \%$ du PIB? [online], 2017. 04. 18. Forrás: LeMonde.fr [2018. 03.07.]

Projet de loi de finances pour 2017: Défense: préparation et emploi des forces, [online], 2016. 11. 24. Forrás: Sénat.fr [2017. 11. 01.] DOI: https://doi.org/10.1016/S1773-035X(17)30370-2

Quelles priorités, quels défis pour la loi de programmation militaire 2019-2024? [online], 2018. 02. 07. Forrás: Jean-jaures.org [2018. 04. 01.]

Revue Stratégique De Défense Et De Sécurité Nationale, [online], 2017. Forrás: Defense.gouv.fr [2017. 10. 15.]

UK and France commit to new defence cooperation, [online], 2018. 01. 18. Forrás: Gov.uk [2018. 03. 01.]

United States Pledging up to \$60 Million in New Support for Security Assistance in the Sahel Region, [online], 2017. 10. 20. Forrás: State.gov [2017. 11. 01.]

Wales Declaration on the Transatlantic Bond, [online], 2014. 09. 05. Forrás: Nato.int [2018. 03. 07.]

Wales Summit Declaration, [online], 2014. 09. 05. Forrás: Nato.int [2018. 03. 07.]

West African and French leaders launch Sahel force, [online], 2017. 07. 03. Forrás: Aljazeera.com [2017. 11. 01.] 